\title{
Growth hormone regulates the expression of hepatocyte nuclear factor-3 gamma and other liver-enriched transcription factors in the bovine liver
}

\author{
S Eleswarapu and $\mathbf{H}$ Jiang \\ Department of Animal and Poultry Sciences, Virginia Polytechnic Institute and State University, Blacksburg, Virginia 24061, USA \\ (Requests for offprints should be addressed to H Jiang; Email: hojiang@vt.edu)
}

\begin{abstract}
Growth hormone $(\mathrm{GH})$ regulates the expression of many genes in the liver, and for some genes this regulation may be mediated through liver-enriched transcription factors (LETFs). As part of the long-term goal to investigate the role of LETFs in GH regulation of gene expression in the liver, in this study we determined the effect of GH administration on the expression of 10 LETFs, including hepatocyte nuclear factor (HNF)-1 $\alpha$, HNF-1 $\beta$, HNF-3 $\alpha$, HNF-3 $\beta$, HNF-3 $\gamma$, HNF-4 $\alpha$, HNF-6, CCAAT/ enhancer-binding protein $(\mathrm{C} / \mathrm{EBP}) \alpha, \mathrm{C} / \mathrm{EBP} \beta$, and albumin D-element binding protein (DBP) in the bovine liver. Eighteen non-lactating and non-pregnant Angus cows were assigned randomly to three groups ( $n=6$ per group) and each cow received a single intramuscular injection of $500 \mathrm{mg}$ slow-release recombinant bovine GH. Liver biopsy samples were taken from group 1 cows $6 \mathrm{~h}$ after GH administration, from group 2 cows $24 \mathrm{~h}$ after $\mathrm{GH}$ administration, and from group 3 cows 1 week after $\mathrm{GH}$ administration. Liver biopsies were also collected from group 3 cows 1 day before $\mathrm{GH}$ administration, serving as pre-GH controls. The LETF mRNAs in these liver samples were quantified using ribonuclease protection assays with probes generated from bovine LETF cDNAs cloned by standard reverse transcription-polymerase chain reaction. The levels of HNF-3 $\gamma$ and HNF-6 mRNAs were higher $(P<0 \cdot 05)$ in the cows $24 \mathrm{~h}$ and 1 week after $\mathrm{GH}$ administration than in the untreated cows or the cows $6 \mathrm{~h}$ after $\mathrm{GH}$ administration. The levels of HNF- $4 \alpha$
\end{abstract}

mRNA were higher $(P<0 \cdot 05)$ in the cows 1 week after $\mathrm{GH}$ administration than in the other three groups of cows. The levels of $\mathrm{C} / \mathrm{EBP} \alpha \mathrm{mRNA}$ were higher $(P<0 \cdot 05)$ in the cows $24 \mathrm{~h}$ after $\mathrm{GH}$ administration than in the untreated cows or the cows $6 \mathrm{~h}$ after $\mathrm{GH}$ administration. The levels of HNF-3 $\beta$ mRNA were higher $(P<0 \cdot 05)$ in the cows $6 \mathrm{~h}$ after $\mathrm{GH}$ administration but were lower $(P<0 \cdot 05)$ in the cows $24 \mathrm{~h}$ or 1 week after GH administration compared with those in the untreated cows. The levels of DBP mRNA were higher $(P<0.05)$ in the cows $6 \mathrm{~h}$ after $\mathrm{GH}$ administration but were lower $(P<0 \cdot 05)$ in the cows $24 \mathrm{~h}$ after $\mathrm{GH}$ administration compared with those in the untreated cows. The levels of HNF-1 $\alpha$, HNF-3 $\alpha$, and C/EBP $\beta$ mRNAs were not different $(P>0 \cdot 05)$ between groups. The expression of HNF-1 $\beta$ mRNA was not detectable. Thus, the expression of six LETFs including HNF-3 $\gamma$, HNF-3 $\beta$, HNF-4 $\alpha$, HNF-6, $\mathrm{C} / \mathrm{EBP} \alpha$, and $\mathrm{DBP}$ mRNAs in the bovine liver is regulated by $\mathrm{GH}$, and these six LETFs may play a role in mediating $\mathrm{GH}$ regulation of gene expression in the liver. Among the 10 LETFs, the response of HNF- $3 \gamma$ to GH is most significant. Cloning and sequencing the promoter region of this gene revealed multiple putative binding elements for signal transducers and activators of transcription 5 (STAT5), suggesting that $\mathrm{GH}$ regulation of HNF-3 $\gamma$ expression in the liver may be mediated through direct binding of STAT5 to the HNF-3 $\gamma$ promoter.

Journal of Endocrinology (2005) 184, 95-105

\section{Introduction}

Growth hormone $(\mathrm{GH})$ is a pituitary polypeptide hormone that plays a central role in animal growth and metabolism (Harvey et al. 1995). A major target organ of GH is the liver, where $\mathrm{GH}$ regulates the expression of many genes. Earlier gene expression studies using Northern blots showed that GH regulated the expression of insulin-like growth factor-I (IGF-I) (Mathews et al. 1986), IGF binding protein (IGFBP)-1 (Seneviratne et al. 1990), IGFBP-3 (Lemmey et al. 1997), the acid labile subunit (ALS) of the IGF binding complex (Ooi et al. 1997), serine protease inhibitor (Spi) 2.1 (Yoon et al. 1990), suppressors of cytokine signaling (SOCS) genes (Tollet-Egnell et al. 1999), phosphoenol pyruvate kinase $C$ and glucose transporter GLUT-2 (Valera et al. 1993), as well as the transcription factors c-fos and c-jun (Gronowski \& Rotwein 1995). More recent gene expression studies 
employing the microarray technology have identified many more GH-regulated genes in the liver. A gene expression analysis with a cDNA array containing 588 rat cDNAs identified eight novel transcripts from the rat liver that were regulated by GH (Thompson et al. 2000). Using a cDNA microarray representing 3000 rat sequences, Flores-Morales et al. (2001) found that 58 of 720 detectable mRNAs were regulated by $\mathrm{GH}$ in the rat liver, many of which were not previously known to be GH responsive. Using a microarray containing 11000 rat expression sequence tags (ESTs), Olsson et al. (2003) identified 58 metabolic genes (i.e. genes involved in metabolism) whose expression in the liver was altered by overexpressed bovine $\mathrm{GH}$ in transgenic mice. Using a microarray consisting of 5889 unique rat genes, Ahluwalia et al. (2004) identified 27 female- and 44 male-predominant genes that were regulated by $\mathrm{GH}$ in the rat liver. These $\mathrm{GH}$-regulated genes are involved in metabolism, detoxification, growth control and other functions of the liver (Thompson et al. 2000, Flores-Morales et al. 2001, Olsson et al. 2003, Ahluwalia et al. 2004). Thus, regulation of gene expression appears to be a major mechanism by which GH affects the function of the liver.

The signaling pathways by which $\mathrm{GH}$ regulates gene expression in the liver are only beginning to be understood (Herrington \& Carter-Su 2001, Schwartz et al. 2002), including the identification of the signal transducers and activators of transcription (STAT), especially STAT5B and STAT5A, as key transcription factors mediating $\mathrm{GH}$ regulation of the expression of Spi 2.1 (Bergad et al. 1995), IGF-I (Woelfle et al. 2003) and several other members of the GH/IGF axis in the liver (Davey et al. 1999, Woelfle \& Rotwein 2004). However, for most of the GHregulated genes, the signaling pathways and the transcription factors involved remain to be elucidated. The expression of thousands of genes in the liver is directly or indirectly controlled by liver-enriched transcription factors (LETFs), including hepatocyte nuclear factor (HNF)-1 $\alpha$, HNF-1 $\beta$, HNF-3 $\alpha$, HNF-3 $\beta$, HNF-3 $\gamma$, HNF-4 $\alpha$, HNF-6, albumin D-element binding protein (DBP), and $\mathrm{CCAAT} /$ enhancer-binding proteins $(\mathrm{C} / \mathrm{EBP}) \alpha$ and C/EBP $\beta$ (Schrem et al. 2002, Odom et al. 2004). Thus, $\mathrm{GH}$ regulation of gene expression of at least some genes in the liver may be mediated through LETFs. Supporting the involvement of LETFs in GH regulation of gene expression in the liver are recent demonstrations that $\mathrm{C} / \mathrm{EBP} \beta$ contributes to $\mathrm{GH}$ regulation of $\mathrm{c}-\mathrm{fos}$ expression (Liao et al. 1999), HNF-3 $\beta$ contributes to $\mathrm{GH}$ regulation of cytochrome P450 (CYP) 2A2, CYP4A2 and CYP2C11 expression (Park \& Waxman 2001), and that HNF-3, HNF-4 and HNF-6 contribute to GH regulation of CYP2C12 expression (Sasaki et al. 1999, DelesqueTouchard et al. 2000) in the liver.

To identify LETFs that might be involved in GH regulation of gene expression in the liver of cattle, in this study we have determined the effect of administration of $\mathrm{GH}$ on the expression of 10 LETFs in the bovine liver.

\section{Materials and Methods}

\section{Animal experiments}

A total of 18 non-lactating and non-pregnant Angus beef cows were used in this study. Each cow had free access to grass and water. The cows were randomly assigned to three groups (groups 1, 2, and 3) with each group containing six cows. Each cow received a single intramuscular injection of $500 \mathrm{mg}$ recombinant bovine $\mathrm{GH}$ in a slow-release formula (Monsanto Company, St Louis, MO, USA). Liver biopsy samples were taken from group 1 cows $6 \mathrm{~h}$ after $\mathrm{GH}$ administration, from group 2 cows $24 \mathrm{~h}$ after $\mathrm{GH}$ injection, and from group 3 cows 1 week after GH administration. Liver biopsy samples were also taken from group 3 cows 1 day before GH administration, serving as pre-GH controls.

The liver biopsy was performed as described before (Oxender et al. 1971). Briefly, the skin area between the 11 th and 12th ribs was washed, sterilized with $70 \%$ ethanol, shaved, and $10 \mathrm{ml}$ lidocaine were administered subcutaneously. A small incision was made between the 11 th and 12th ribs and the biopsy needle (Sontec Instruments, Inc., Englewood, CO, USA) was introduced to the liver through the skin incision. A liver sample of 100$300 \mathrm{mg}$ was collected from each cow. Once taken, liver samples were immediately frozen in liquid nitrogen and stored at $-80{ }^{\circ} \mathrm{C}$. The animal-related procedures were approved by the Virginia Tech Animal Care Committee.

\section{$R N A$ and DNA extraction}

Total RNA from liver tissue samples was isolated by using TRI reagent (MRC, Cincinnati, OH, USA) and poly(A) RNA was isolated from total RNA using the Oligotex mRNA kit (Qiagen, Chatsworth, CA, USA), according to the manufacturers' instructions. Genomic DNA from bovine liver tissue was isolated by standard proteinase $\mathrm{K}$ digestion followed by phenol-chloroform extraction. The concentration and quality of extracted RNA and DNA were determined by spectrometry and gel-electrophoresis respectively.

\section{Reverse transcription-polymerase chain reaction (RT-PCR) and PCR}

The RT-PCR was used to clone the cDNA fragments for nine bovine LETFs, including HNF-1 $\alpha$, HNF-1 $\beta$, HNF-3 $\alpha, \quad$ HNF-3 $\beta$, HNF-3 $\gamma$, HNF-6, C/EBP $\alpha$, $\mathrm{C} / \mathrm{EBP} \beta$, and DBP. The reverse transcription (total volume $20 \mu \mathrm{l}$ ), containing $2 \mu \mathrm{g}$ bovine liver mRNA, $1 \mu \mathrm{g}$ oligo (dT) primer or $0.5 \mu \mathrm{g}$ random hexamer primers 
Table 1 Oligonucleotide primers used for PCR amplification of bovine LETF cDNAs and DNA

\begin{tabular}{|c|c|c|}
\hline & Primers* & Corresponding region \\
\hline \multicolumn{3}{|l|}{ LETF } \\
\hline \multirow[t]{2}{*}{ HNF-1 $\alpha$} & Forward primer: GCCTATGAGAGGCAGAAGAA & Coding \\
\hline & Reverse primer: CGTGTCCATGGCCAGCTTG & \\
\hline \multirow[t]{2}{*}{ HNF-1 $\beta$} & Forward primer: GAGCCCACCAACAAGAAGAT & Coding \\
\hline & Reverse primer: CATGGCCAGCTTCTGCCGG & \\
\hline \multirow[t]{2}{*}{ HNF-3 $\alpha$} & Forward primer: CСGТТСТССАТСААСААССТ & Coding \\
\hline & Reverse primer: GTGTITAGGACGGGTCTGGA & \\
\hline \multirow[t]{2}{*}{ HNF-3 $\beta$} & Forward primer: TGGGAGCGGTGAAGATGGA & Coding \\
\hline & Reverse primer: GCCCGCGCCGGGGGACAT & \\
\hline \multirow[t]{2}{*}{ HNF-3 $\gamma$} & Forward primer: CTTCAAGCTGGAGGAG & Promoter \\
\hline & Reverse primer: GCTGGTGTCTGTTCTGACAT & \\
\hline \multirow[t]{2}{*}{ HNF-3 $\gamma$} & Forward primer: GCCGCCGGGAAATGGAGTCC & Coding \\
\hline & Reverse primer: CCATCTTCACTGAGCCCAGCAT & \\
\hline \multirow[t]{2}{*}{ HNF-6 } & Forward primer: CTGCAGGAGCCGGAGTTCCA & Coding \\
\hline & Reverse primer: ССАСТTGTССАGАСТССТСС & \\
\hline \multirow[t]{2}{*}{ DBP } & Forward primer: CCTCGAAGACATCGСТTCTC & Coding \\
\hline & Reverse primer: GCACCGATATCTGGTTCTCC & \\
\hline \multirow[t]{2}{*}{$\mathrm{C} / \mathrm{EBP} \alpha$} & Forward primer: TGGCCGACCTGTTCCAACA & Coding \\
\hline & Reverse primer CCCCGACCCGCTCGTACA & \\
\hline \multirow[t]{2}{*}{$\mathrm{C} / \mathrm{EBP} \beta$} & Forward primer: ATCGACTTCAGССССТАССТ & Coding \\
\hline & Reverse primer: CGTAGTCGTCGGAGAAGAG & \\
\hline
\end{tabular}

(Promega, Madison, WI, USA), 0.01 M dithiothreitol, $0.5 \mathrm{mM}$ deoxyribonucleotide triphosphates (dNTP) (Invitrogen, Carlsbad, CA, USA), 200 U SuperScript II reverse transcriptase (Invitrogen) and $4 \mu \mathrm{l} 5 \times$ reverse transcription buffer (Promega), was performed at $42{ }^{\circ} \mathrm{C}$ for $2 \mathrm{~h}$. For the PCR amplification of each bovine LETF cDNA, $2 \mu \mathrm{l}$ of the reverse transcription products were mixed with $12.5 \mu \mathrm{l} 2 \times$ PCR master mix (Promega) and $10 \mathrm{pmol}$ LETF-specific forward and reverse primers (Table 1), which were designed based on the mRNA sequences of the human, ovine, or rodent LETFs, in a total volume of $25 \mu \mathrm{l}$. The PCR amplification was initiated by heating at $94{ }^{\circ} \mathrm{C}$ for $3 \mathrm{~min}$, followed by 35 cycles of $30 \mathrm{~s}$ at $94{ }^{\circ} \mathrm{C}, 1 \mathrm{~min}$ at $60{ }^{\circ} \mathrm{C}$ (for $\mathrm{C} / \mathrm{EBP} \beta$ and DBP) or $55^{\circ} \mathrm{C}$ (for other LETFs), and $1 \mathrm{~min}$ at $72{ }^{\circ} \mathrm{C}$. The PCR products were resolved on $1.5 \%$ agarose gels containing ethidium bromide. The DNA bands with the expected sizes were extracted from the gel using gel extraction kits (Qiagen), according to the manufacturer's instructions.

A standard PCR was used to amplify the promoter region of the bovine $\mathrm{HNF}-3 \gamma$ gene, with forward and reverse primers (Table 1) that were designed based on the homologous DNA sequences between the $5^{\prime}$-flanking regions of the human and mouse $\mathrm{HNF}-3 \gamma$ genes. The conditions of this PCR were 35 cycles of $30 \mathrm{~s}$ at $94{ }^{\circ} \mathrm{C}$, $1 \mathrm{~min}$ at $60{ }^{\circ} \mathrm{C}$, and $2 \mathrm{~min}$ at $72{ }^{\circ} \mathrm{C}$. The PCR products were analyzed on agarose gels as described above.

\section{Cloning and subcloning}

The gel-extracted LETF cDNAs were ligated into pGEM-T Easy vector (Promega), essentially according to the manufacturer's instructions. The gel-extracted bovine HNF-3 $\gamma$ promoter DNA was inserted into pGL2B vector (Promega) at the NheI and HindIII sites. The ligation was transformed into competent DH10B Escherichia coli (Invitrogen) by electroporation and the positive clones were selected on the LB/Ampicillin/5-bromo-4-choloro-3indolyl- $\beta$-D-galactoside (X-Gal)/isopropyl thiogalactoside (IPTG) plates. The plasmid DNA from the selected E. coli cells was extracted using the Qiagen miniprep kit (Qiagen) according to the manufacturer's instructions and analyzed for inclusion of inserts by digestion with restriction enzyme EcoRI. In addition, the HNF-1 $\alpha$ and HNF-3 $\gamma$ cDNA inserts in their respective pGEM-T Easy plasmids were released with restriction enzymes SpeI and EcoRI and were subcloned into pGEM-4Z vector (Promega) between cloning sites EcoRI and XbaI.

\section{Sequencing and sequence analysis}

The sequencing reaction was set up with $400 \mathrm{ng}$ of the plasmid and 5 pmol vector specific primers in a volume of $10 \mu \mathrm{l}$ using the ABI Prism Big Dye Terminator cycle sequencing chemistry (Applied Biosystems, Foster City, CA, USA), run at $96^{\circ} \mathrm{C}$ for $1 \mathrm{~min}$, followed by 49 cycles of $96{ }^{\circ} \mathrm{C}$ for $10 \mathrm{~s}, 50{ }^{\circ} \mathrm{C}$ for $10 \mathrm{~s}$, and $60{ }^{\circ} \mathrm{C}$ for $4 \mathrm{~min}$. The sequencing reactions were analyzed on ABI 377 Automated DNA Sequencers (Applied Biosystems). The nucleotide sequences of the cloned bovine LETF cDNAs and HNF-3 $\gamma$ promoter DNA were compared with the sequences in GenBank using the BLAST program at http://www.ncbi.nlm.nih.gov. Multiple 
Table 2 Cloning information of the bovine LETF cDNA plasmids

\begin{tabular}{|c|c|c|c|c|c|}
\hline & $\begin{array}{l}\text { Insert size } \\
\text { (bp) }\end{array}$ & $\begin{array}{l}\text { GenBank accession } \\
\text { number }\end{array}$ & Cloning sites & $\begin{array}{l}\text { Restriction enzymes to } \\
\text { linearize plasmid for } \\
\text { antisense RNA synthesis }\end{array}$ & $\begin{array}{l}\text { RNA polymerase to } \\
\text { synthesize antisense } \\
\text { riboprobe }\end{array}$ \\
\hline \multicolumn{6}{|l|}{ Plasmid name* } \\
\hline pGEM-TE-bHNF- $1 \beta$ & 273 & AY621541 & EcoRI/EcoRI & Spel & $\mathrm{T7}$ \\
\hline pGEM-TE-bHNF-3 $\alpha$ & 218 & AY621542 & EcoRI/EcoRI & Spel & T7 \\
\hline pGEM-TE-bHNF-3 $\beta$ & 251 & AY621543 & EcoRI/EcoRI & Spel & T7 \\
\hline pGEM-TE-bDBP & 184 & AY 621548 & EcoRI/EcoRI & Spel & $\mathrm{T7}$ \\
\hline pGEM-TE-bC/EBP $\alpha$ & 216 & AY521546 & EcoRI/EcoRI & Ncol & SP6 \\
\hline pGEM-TE-bC/EBP $\beta$ & 163 & AY621547 & EcoRI/EcoRI & Ncol & SP6 \\
\hline
\end{tabular}

*pGEM-TE, pGEM-T Easy vector (Promega); b, bovine

sequence alignment was performed with the ClustalW program at http://www.ebi.ac.uk.

\section{In vitro transcription}

The bovine LETF cDNA-containing plasmids cloned in this study as well as the bovine HNF-4 $\alpha$ cDNA (311 bp) plasmid cloned in a previous study (Jiang \& Lucy 2001) were linearized with appropriate restriction enzymes (Table 2). About $0.5 \mu \mathrm{g}$ of each linearized plasmid was transcribed in vitro with either T7 or SP6 RNA polymerase (Table 2) in the presence of $\left[\alpha_{-}{ }^{32} \mathrm{P}\right] \mathrm{CTP}$ to generate antisense riboprobe for each LETF mRNA. The in vitro transcription was carried out using the Riboprobe Combination System kit (Promega), essentially according to the manufacturer's instructions. After transcription, free $\left[\alpha-{ }^{32} \mathrm{P}\right] \mathrm{CTP}$ was removed from the probe by phenolchloroform extraction and filtration through quick spin Sephadex G-50 columns (Roche Molecular Biochemicals, Indianapolis, IN, USA). The specific activity of the purified probe was estimated by liquid scintillation counting.

\section{Ribonuclease protection assay (RPA)}

The RPA was carried out using the RPA II kit (Ambion, Austin, TX, USA) according to the manufacturer's instructions. Briefly, $20 \mu \mathrm{g}$ total liver RNA, $1 \times 10^{5}$ c.p.m. of one or two LETF riboprobes $(\mathrm{C} / \mathrm{EBP} \alpha$ and $\mathrm{C} / \mathrm{EBP} \beta$ mRNAs were analyzed in the same RPA, as were DBP and HNF- $3 \beta$ mRNAs), and $1 \times 10^{5}$ c.p.m. glyceraldehyde3 -phosphate dehydrogenase (GAPDH) probe, which was synthesized as described before (Wang et al. 2003), were mixed in $20 \mu \mathrm{l}$ hybridization buffer. The mixture was incubated at $42{ }^{\circ} \mathrm{C}$ for about $16 \mathrm{~h}$ and then digested with $200 \mu \mathrm{l}$ 1:100 diluted ribonucleases $\mathrm{A}$ and $\mathrm{T}_{1}$ at $37^{\circ} \mathrm{C}$ for $45 \mathrm{~min}$. The undigested RNA fragments were precipitated and resolved on 6\% polyacrylamide gels containing $7 \mathrm{M}$ urea. The gels were dried, exposed to phosphor- screens, and scanned on a Molecular Imager FX System (BioRad, Hercules, CA, USA). The intensity of each protected band was measured using the Alpha Imager program (Alpha Innotech Corporation, San Leandro, CA, USA) and was used to represent the abundance of the corresponding mRNA. The intensity of the LETF mRNA band was adjusted to that of the GAPDH mRNA in the same sample to normalize variations in the starting amounts of RNA and variations in performing RPA.

Besides LETF mRNAs, IGF-I mRNA was also quantified in the liver samples, serving as a positive control for $\mathrm{GH}$ regulation of gene expression in the liver of cows. This RPA was performed essentially as described before (Wang et al. 2003).

\section{Statistical analysis}

The LETF mRNA levels of different groups of cows were compared using General Linear Model ANOVA and Tukey's procedures of SAS (SAS Institute, Cary, NC, USA). Differences were considered significant if $P<0 \cdot 05$. All data were expressed as means \pm S.E.M. (standard error of the mean).

\section{Results}

\section{Sequences of bovine LETF cDNAs}

cDNA fragments between 150 base pair (bp) and $350 \mathrm{bp}$ for bovine HNF-1 $\alpha$, HNF-1 $\beta$, HNF-3 $\alpha$, HNF-3 $\beta$, HNF-3 $\gamma$, HNF-6, DBP, C/EBP $\alpha$, and C/EBP $\beta$ were cloned and sequenced (Table 2). The sequences have been deposited in GenBank (Table 2). The sequences of the cloned bovine LETF cDNA fragments, except HNF-3 $\gamma$, share more than $90 \%$ and $84 \%$ identities with the corresponding human and mouse LETF sequences respectively. The bovine HNF- $3 \gamma$ sequence is $85 \%$ and $78 \%$ identical to the human and mouse HNF-3 $\gamma$ sequences respectively. 
All 10 LETFs except HNF-1 $\beta$ mRNA were detectable by RPA in the cow liver

The RPAs of $20 \mu \mathrm{g}$ total RNA detected significant expression of all ten LETFs except HNF-1 $\beta$ in the liver of both GH-treated and untreated cows (Figs $1 \mathrm{~A}$ and $2 \mathrm{~A}$ ). (The RPA image for HNF-1 $\beta$ is not shown.) However, HNF-1 $\beta$ mRNA was detectable in fetal bovine liver (data not shown). The HNF-1 $\beta$ mRNA is probably expressed at very low levels in the adult cow liver and GH probably does not strongly stimulate HNF- $1 \beta$ expression in the cow liver, if it has any stimulatory effect.

\section{GH strongly stimulated HNF- $3 \gamma$ expression}

As revealed by RPAs (Fig. 1A), the liver expression of HNF- $3 \gamma$ mRNA in the cows $24 \mathrm{~h}$ and 1 week after GH administration was higher $(P<0 \cdot 05)$ than in the untreated cows or in the cows $6 \mathrm{~h}$ after $\mathrm{GH}$ administration (Fig. 1B). The liver levels of HNF-3 $\gamma$ mRNA were, however, not different between the untreated cows and the cows $6 \mathrm{~h}$ after $\mathrm{GH}$ administration, or between the cows $24 \mathrm{~h}$ after $\mathrm{GH}$ administration and the cows 1 week after $\mathrm{GH}$ administration (Fig. 1A,B). GH administration increased the HNF-3 $\gamma$ mRNA expression by more than fourfold (Fig. 1B). This magnitude of increase was the greatest among the GH-induced increases in all LETF mRNAs (Fig. 1B) and was comparable to that of the GH-induced increase in the expression of IGF-I mRNA (Fig. 1A,B), a widely known target of $\mathrm{GH}$ action in the liver.

\section{GH stimulated HNF-6, HNF-4a, and C/EB- $\alpha$ expression weakly with different kinetics}

The levels of HNF- $4 \alpha$ mRNA in the liver of the cows 1 week after $\mathrm{GH}$ administration were higher $(P<0 \cdot 05)$ than in the untreated cows (Fig. 1A,B). The levels of HNF- $4 \alpha$ mRNA were not different between the cows $6 \mathrm{~h}$ or $24 \mathrm{~h}$ after $\mathrm{GH}$ administration and the untreated cows (Fig. $1 \mathrm{~A}, \mathrm{~B})$. Thus, $\mathrm{GH}$ administration increased the expression of HNF- $4 \alpha$ mRNA in the liver of cows, but this effect appeared to take a longer time than did the effect of $\mathrm{GH}$ on HNF-3 $\gamma$ or IGF-I expression (Fig. 1A).

The RPA with a probe transcribed from the cloned HNF-6 cDNA generated two ribonuclease-protected mRNA fragments across the liver RNA samples (Fig. 1A). The longer band was apparently at the size (273 bp) of the cloned HNF-6 cDNA and the shorter protected fragment was approximately $225 \mathrm{bp}$. These two protected bands corresponded to the HNF-6 mRNA splice variants, HNF- $6 \alpha$ mRNA and HNF-6 $\beta$ mRNA, which contains an insertion $43 \mathrm{bp}$ downstream from the $5^{\prime}$ end of the cloned HNF- $6 \alpha$ cDNA, based on the sequences of the mouse HNF-6 $\alpha$ and HNF-6 $\beta$ mRNAs (Lemaigre et al. 1996). As in the mouse liver (Lemaigre et al. 1996), the HNF- $6 \alpha$ mRNA was expressed at a higher level than the
HNF-6 3 mRNA in the bovine liver (Fig. 1A). The levels of both HNF- $6 \alpha$ and HNF- $6 \beta$ mRNAs in the liver of the cows $24 \mathrm{~h}$ and 1 week after $\mathrm{GH}$ administration were higher $(P<0 \cdot 05)$ than in the untreated cows or the cows $6 \mathrm{~h}$ after $\mathrm{GH}$ administration (Fig. 1B). However, the levels of HNF- $6 \alpha$ and HNF- $6 \beta$ mRNAs were not different between the cows $6 \mathrm{~h}$ after $\mathrm{GH}$ administration and the untreated cows, or between the cows $24 \mathrm{~h}$ after $\mathrm{GH}$ administration and the cows 1 week after GH administration (Fig. 1B).

$\mathrm{GH}$ administration also increased $\mathrm{C} / \mathrm{EBP} \alpha$ mRNA expression in the liver, as the levels of C/EBP $\alpha$ mRNA were higher $(P<0 \cdot 05)$ in the cows $24 \mathrm{~h}$ after $\mathrm{GH}$ administration than in the untreated cows (Fig. 1A,B). In contrast to the stimulation of GH on HNF-3 $\gamma$, HNF-6, and IGF-I mRNA expression, GH stimulation of C/EBP $\alpha$ expression appeared to be temporary, as the levels of C/EBPa mRNA were not different between the cows 1 week after $\mathrm{GH}$ administration and the untreated cows (Fig. 1A,B).

GH had initially a stimulatory effect and subsequently an inhibitory effect on liver expression of HNF-3 $\beta$ and DBP $m R N A s$

Growth hormone appeared to have a transient stimulatory but a sustained inhibitory effect on the expression of HNF-3 $\beta$ mRNA in the bovine liver, as the levels of HNF-3 $\beta$ mRNA were higher $(P<0 \cdot 05)$ in the cows $6 \mathrm{~h}$ after $\mathrm{GH}$ administration but lower $(P=0 \cdot 05)$ in the cows $24 \mathrm{~h}$ and 1 week after $\mathrm{GH}$ administration compared with those in the untreated cows (Fig. 1A,B).

The RPA with a probe transcribed from the cloned DBP cDNA generated two ribonuclease-protected mRNA fragments across the liver RNA samples (Fig. 1A). The longer band, in the size (184 bp) of the cloned DBP cDNA insert, corresponded to the cloned bovine DBP mRNA sequence. The shorter band, in the same expression pattern as the longer band across the samples (Fig. 1A), probably represented an unidentified splice variant of DBP mRNA. Compared with the untreated cows, the cows $6 \mathrm{~h}$ after $\mathrm{GH}$ administration had increased expression $(P<0 \cdot 05)$ of DBP mRNA (both the long and the short bands), the cows $24 \mathrm{~h}$ after $\mathrm{GH}$ administration had decreased expression $(P<0 \cdot 05)$, and the cows 1 week after $\mathrm{GH}$ administration had similar levels of DBP mRNA in the liver (Fig. 1A,B). Thus, like its effect on HNF-3 $\beta$, GH initially had a stimulatory effect and then an inhibitory effect on DBP mRNA expression in the liver of cows.

\section{GH had no effect on HNF-1a, C/EBP $\beta$ and HNF-3a $m R N A$ expression}

The liver mRNA levels of other LETFs, including HNF$1 \alpha, \mathrm{HNF}-3 \alpha$, and C/EBP $\beta$, were not different between the cows 6 h, 24 h, and 1 week after GH administration 

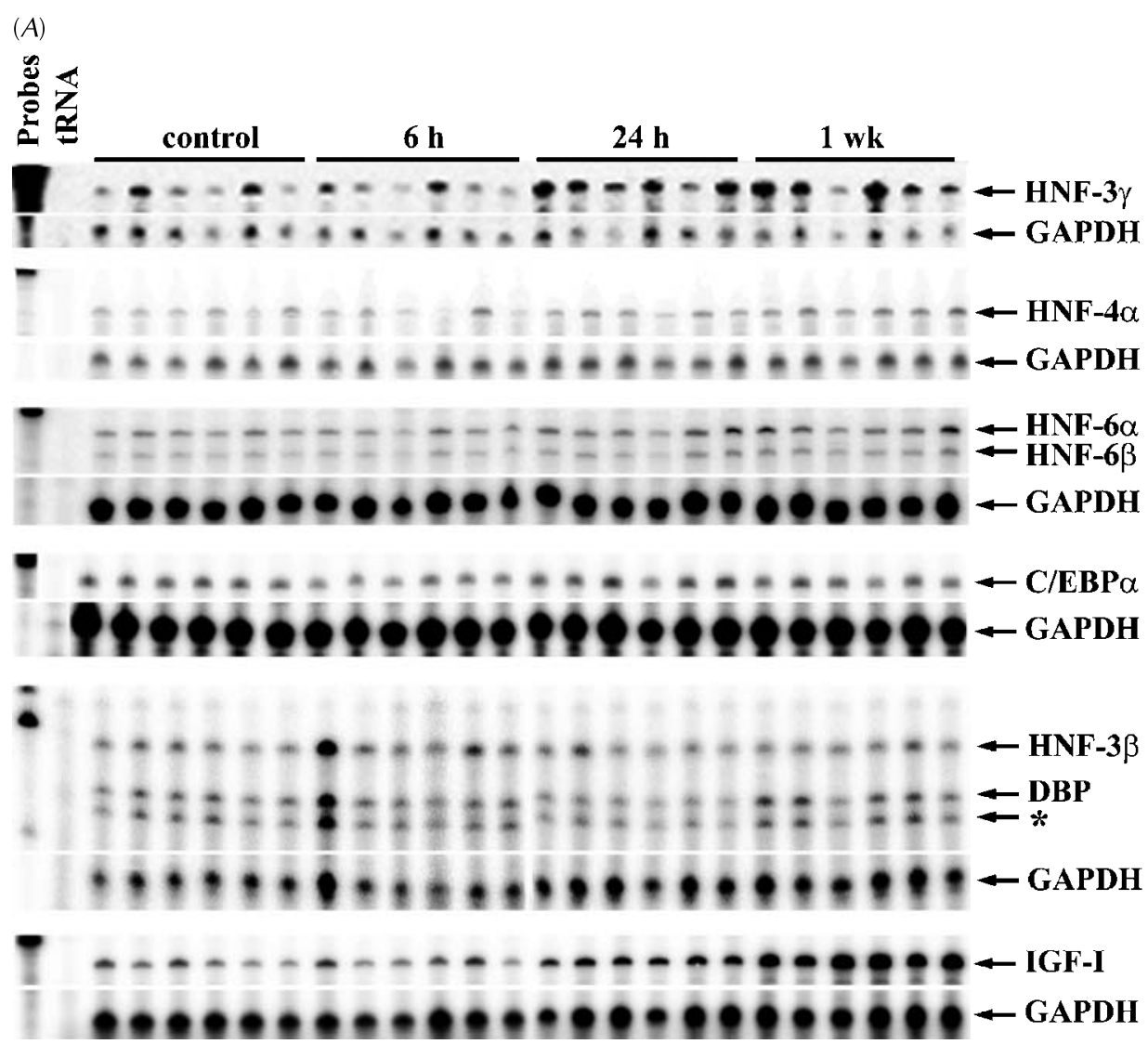

(B)

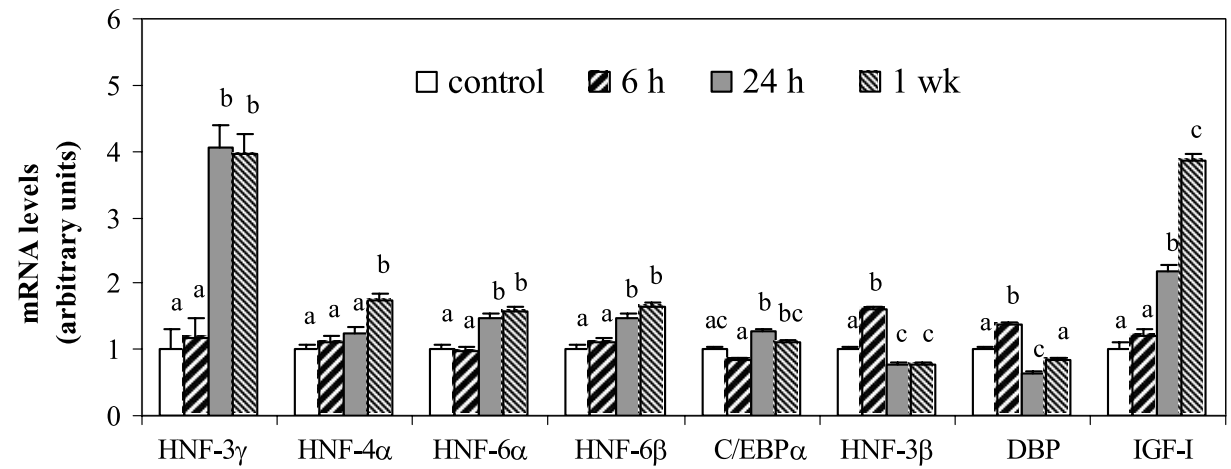

Figure 1 RPAs of HNF- $3 \gamma$, HNF- $4 \alpha$, HNF-6, C/EBP $\alpha, H N F-3 \beta$, and DBP mRNAs in the livers of cows $6 \mathrm{~h}, 24 \mathrm{~h}$, and 1 week after GH administration as well as untreated cows (control). (A) Phosphor images of the RPAs. In the RPA of each LETF mRNA, a probe specific for GAPDH mRNA was also included as a control for variations in starting amounts of RNA and the variations in performing RPA. Yeast tRNA (tRNA) was included in the RPA as a negative control. The ribonuclease-protected fragments corresponding to specific LETF and GAPDH mRNAs are indicated with arrows. The RPA of HNF-6 mRNA generated two protected bands that corresponded to splice variants HNF-6 $\alpha$ and HNF-6 3 (see text for details). The asterisk indicates a potentially unidentified DBP mRNA splice variant. The RPA for IGF-I mRNA served as a positive control for $\mathrm{GH}$ regulation of gene expression in the liver. (B) Relative abundance of HNF-3 $\gamma$, HNF- $4 \alpha$, HNF- $6 \alpha$, HNF- $6 \beta, \mathrm{C} / \mathrm{EBP} \alpha, \mathrm{HNF}-3 \beta$, and DBP mRNAs as well as IGF-I mRNA. The relative abundance of each LETF mRNA or IGF-I mRNA was obtained by densitometric analysis of the RPA images in A. The density of each protected LETF or IGF-I mRNA band in each sample was normalized against that of protected GAPDH mRNA measured in the same RPA. All values are expressed as means \pm S.E.M. (pooled). For each mRNA species, the means with different letters are significantly different $(P<0 \cdot 05)$. 


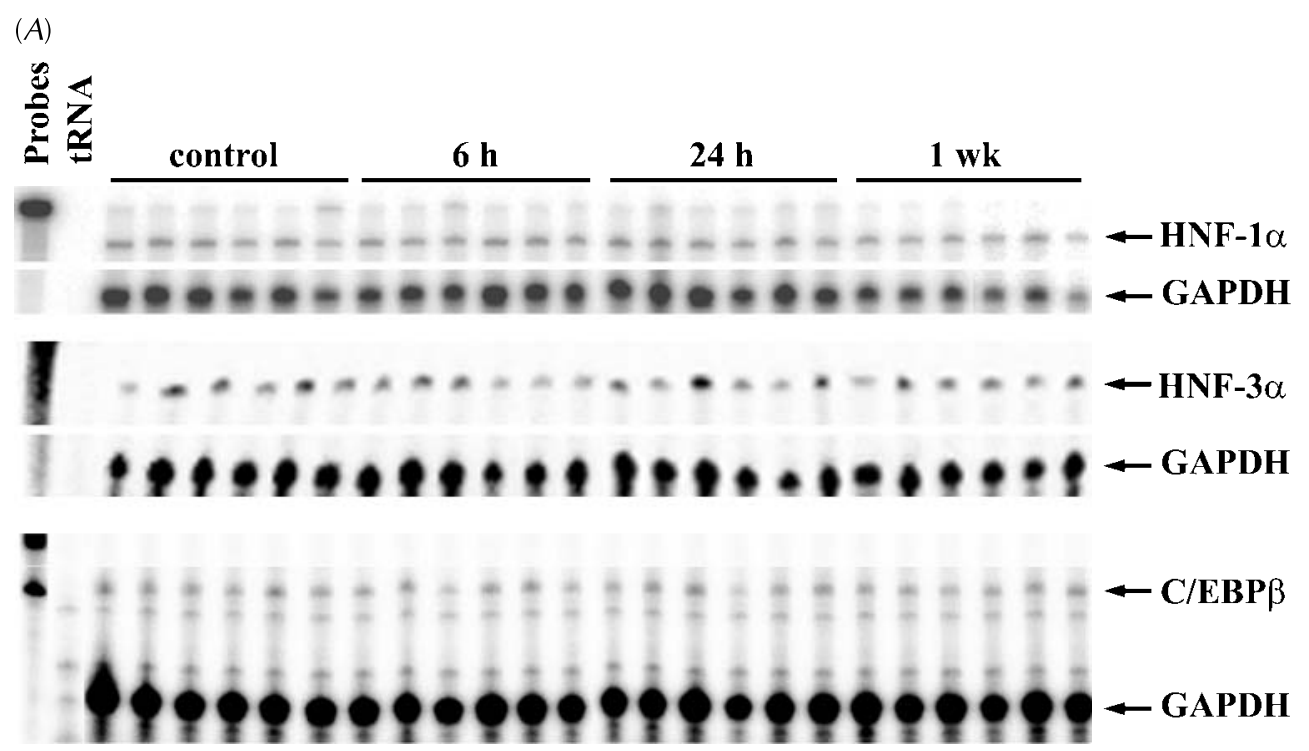

(B)

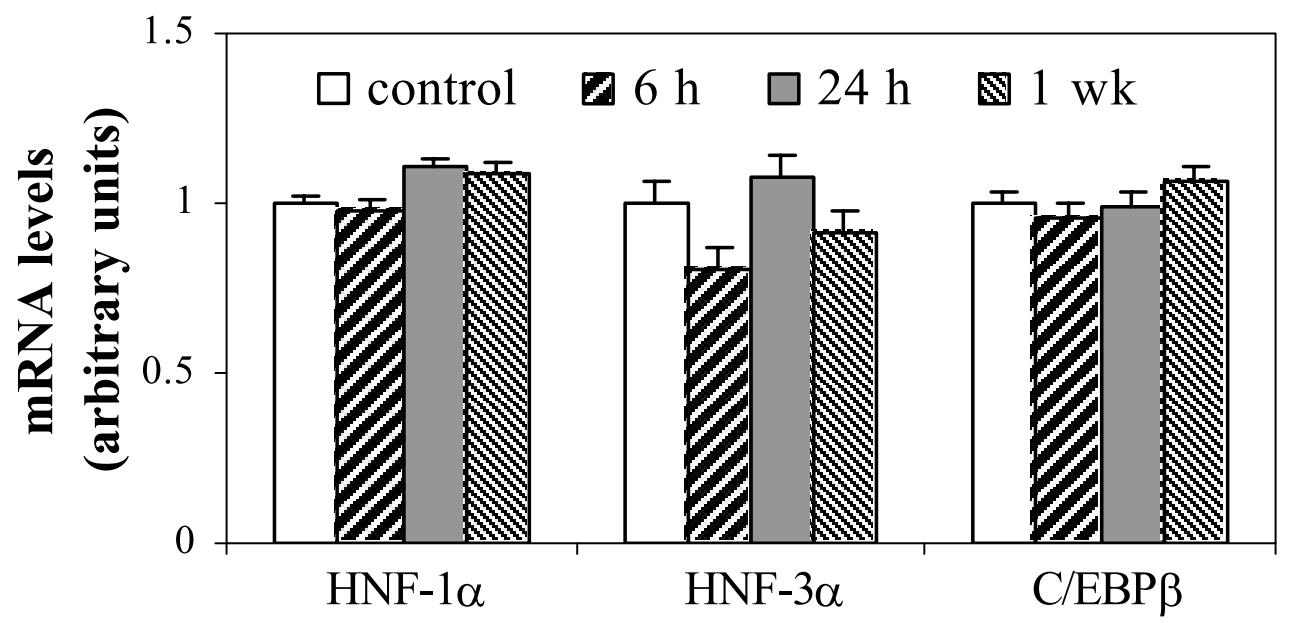

Figure 2 RPAs of HNF-1 $\alpha, \mathrm{HNF}-3 \alpha$, and C/EBP $\beta$ mRNAs in the livers of cows $6 \mathrm{~h}, 24 \mathrm{~h}$, and 1 week after $\mathrm{GH}$ administration as well as untreated cows (control). (A) Phosphor images of the RPAs. (B) Relative abundance of HNF- $1 \alpha, \mathrm{HNF}-3 \alpha$, and C/EBP $\beta$ mRNAs of different groups of cows. All values are expressed as means \pm S.E.M. (pooled). There are no significant differences between the means $(P>0 \cdot 05)$.

and the untreated cows (Fig. 2A,B), indicating that GH had no significant effect on the expression of these three LETF mRNAs in the cow liver.

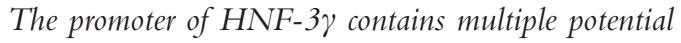
STAT5-binding sites

Among the LETFs, the response of HNF-3 $\gamma$ to GH appeared to be the strongest and was similar in magnitude and time-course to the IGF-I response to GH (Fig. 1). The GH regulation of the expression of IGF-I (Woelfle et al. 2003) and several other genes (Bergad et al. 1995, Davey et al. 1999, Woelfle \& Rotwein 2004) in the liver has been shown to be mediated by STAT5. To determine if GH stimulation of HNF- $3 \gamma$ expression is also mediated by STAT5, a $967 \mathrm{bp}$ promoter region of the bovine HNF-3 $\gamma$ gene was cloned and sequenced (Fig. 3A). A search of this promoter region for transcription factor binding sites revealed three potential STAT5 binding sites (Fig. 3A) that are nearly identical to the consensus STAT5 binding sequence TTCN ${ }_{3}$ GAA (where $\mathrm{N}$ is any nucleotide) (Ehret et al. 2001). Aligning the corresponding DNA regions of the bovine, human, and mouse HNF-3 $\gamma$ genes further revealed that two of the putative STAT5 binding sites are highly conserved among these three species (Fig. 3B). The two STAT5 binding sites are also 
A

\begin{tabular}{|c|c|c|c|c|c|c|}
\hline $\operatorname{tccgccctc}$ & tccttctgcg & aagccegggc & agcecttcat & ttccgtctt & cgggcgccat & 120 \\
\hline ga & a atgtagtcc & tgtgacaggg & gggcgggacg & gaaggggggc & ggaggcttc & 180 \\
\hline ggaaatgg & agttcacgaa & gactctggct & cctggacgg & ctgatgttag & tgaacaga & 240 \\
\hline tcggatagg & cgaagctcct & aggtcttgca & ggttatctcc & agtctcagcg & ggatatgagc & 300 \\
\hline gaggecceg & atccectcca & ccttttgtco & tggccattta & cacaatctgg & agcacttcca & 360 \\
\hline ttatcagac & gctcagtctt & ccagtccgtc & caagggaaa & gtggtttcg & tcct & 42 \\
\hline ccggtcctt & atagtaatag & taacacaacg & gacctctgg & agaccactcg & tctgagcc & 48 \\
\hline ccttccac & tccaacaagt & cttgct & $\operatorname{cctg} \mathrm{C}$ & ccagttgag & aa & 54 \\
\hline ctaagtag & aagggaccta & gagttc & tcgaggctt & atgag & EC & 60 \\
\hline cagttatag & ctccetcact & cttcagccgt & ccccagctct & ctcgtccecg & cggat & 66 \\
\hline $\operatorname{ccggcgcct}$ & gaggtctctc & tcctcgcaat & ccgcagggg & gcgccccaat & $\mathrm{cac}$ & 72 \\
\hline gcceggggg & cgggagcggg & cggg & $\mathrm{Cg}$ & & C & 78 \\
\hline ctataag & $\operatorname{cgtggccgcc}$ & $\operatorname{tccc}$ & ga & t & gg & 84 \\
\hline ggacggg & gcgggtcgga & $\operatorname{actc}$ & $\mathrm{ag}$ & & $y t$ & 90 \\
\hline $\operatorname{cccgggc}$ & ggagagggg & gtg & & 999 & $=9$ & 96 \\
\hline
\end{tabular}

B

$$
\begin{aligned}
& \text { hHNF-3y -GTCCGGCTAGGCCTTCTGGGAAATGTAGTCC---CTTCGGAGGCACCGGGCGGAA } 52 \\
& \text { mHNF-3 } \gamma \text { CGAGCG-CCATGCCTTCTGGGAAATGTAGTCCGCGCTGCGCAGGCGCCGGACGGAA } 55 \\
& \text { bHNF-3 } \gamma \text { CGGGCG-CCATG-CTCTTGGGAAATGTAGTCC-TGTGACAGGGGGGCGGGACGGAA } 53 \\
& \text { hHNF-3 } \\
& \text { mHNF-3 } 7 \text { ATGGGAACGAAGGCTTCTGGGAAATGGAGTTCCCAGCGGTCCGGAGT- } 102 \\
& \text { bHNF-3 } \gamma \text { GGGGGGCTGGAGGCTTCTGGGAAATGGAGTTCACGAAGACTCTGGCT- } 100
\end{aligned}
$$

Figure 3 The promoter of HNF-3 $\gamma$ contains putative STAT5-binding sites. (A) Sequence of a $967 \mathrm{bp}$ promoter region of the bovine HNF-3 $\gamma$ gene. Underlined are three putative STAT5-binding sites; in bold is the translation start codon (ATG) for HNF-3 $\gamma$ protein. (B) Alignment of corresponding regions of the human (h), mouse (m) and bovine (b) HNF-3 $\gamma$ promoters. Shaded are two conserved STAT5 binding sites. The bovine sequence corresponds to the region between 111 and 210 in panel $A$ of this figure. The human and mouse sequences correspond to the region between 92919 and 93018 in GenBank accession number AC008623.4 and the region between 185588 and 185689 in GenBank accession number AC145199.3 respectively.

conserved in the corresponding rat genomic region (data not shown).

\section{Discussion}

The expression of many genes in the liver has been shown to be regulated by GH (Thompson et al. 2000, FloresMorales et al. 2001, Olsson et al. 2003, Ahluwalia et al. 2004). As part of the effort to understand the mechanism by which $\mathrm{GH}$ regulates gene expression in the liver, we have analyzed the effect of administration of slow-release $\mathrm{GH}$ (equivalent to continuous $\mathrm{GH}$ administration) on the expression of 10 LETF genes in the liver of cows. Our data indicate that continuous $\mathrm{GH}$ administration has a sustained stimulatory effect on the expression of HNF-6, HNF- $4 \alpha$, and $\mathrm{C} / \mathrm{EBP} \alpha$, and initially has a stimulatory and subsequently an inhibitory effect on the expression of HNF-3 $\beta$ in the bovine liver. These findings in general agree with the observations from studying the effect of $\mathrm{GH}$ on the expression of HNF-6 (Lahuna et al. 1997), HNF-4 $\alpha$ and HNF-3 $\beta$ (Lahuna et al. 2000) and C/EBP $\alpha$ (Rastegar et al. 2000. Strand et al. 2000) in the liver of hypophysectomized rats or cultured primary hepatocytes. The only major difference is that the GH-induced changes in these LETF mRNAs in cows were much smaller (less than onefold) than those observed in hypophysectomized rats (several folds). The reason for this difference is probably because hypophysectomized rats are much more sensitive to $\mathrm{GH}$ action than pituitary-intact cows.

The data from the present study also indicate that during the one-week course of GH treatment, the expression of HNF-1 $\alpha$ mRNA in the bovine liver was not changed. In earlier studies by others (Le Stunff et al. 1996, Rastegar et al. 2000), the liver levels of HNF-1 $\alpha$ protein in rats were not altered by hypophysectomy or GH replacement. These observations together suggest that GH does not regulate the expression of HNF-1 $\alpha$ in the liver. The effect of $\mathrm{GH}$ on other LETFs, including C/EBP $\beta$, DBP, 
and HNF-3 $\gamma$, has not been reported or suggested by the literature. Our data from this study show that GH administration for one week had no effect on the expression of C/EBP $\beta$ mRNA but had a strong, sustained stimulatory effect on the expression of HNF- $3 \gamma$ mRNA and a biphasic effect, like that on HNF-3 $\beta$, on the expression of DBP mRNA in the bovine liver. Thus, HNF-3 $\gamma$ and DBP are two new LETFs the expression of which is regulated by $\mathrm{GH}$ in the liver.

The mechanism by which $\mathrm{GH}$ regulates the expression of HNF-3 $\gamma, \mathrm{HNF}-3 \beta$, HNF-6, HNF-4 $\alpha$, C/EBP $\alpha$, and DBP mRNAs in the bovine liver was not a focus of this study. However, cloning and sequencing the promoter region of the HNF-3 $\gamma$ gene, the LETF that was most sensitive to $\mathrm{GH}$ regulation, revealed two putative binding sites for STAT5, the same transcription factor that has been shown to be directly involved in GH regulation of the expression of Spi 2.1 (Bergad et al. 1995), IGF-I (Woelfle et al. 2003), ALS (Ooi et al. 1997), and HNF-6 (Lahuna et al. 2000). A sequence alignment further indicated that the sequences of the putative STAT5 binding sites are also conserved in the promoter regions of the human, mouse, and rat HNF-3 $\gamma$ genes. Functionally important cisregulatory regions are often conserved during evolution (Cooper \& Sidow 2003, Thomas et al. 2003). Containing multiple and evolutionally conserved sequences of STAT5 binding sites suggests that GH may regulate HNF-3 $\gamma$ mRNA expression in the liver through direct binding of STAT5 to the HNF-3 $\gamma$ promoter. This potential mechanism, as well as the mechanisms underlying $\mathrm{GH}$ regulation of other LETFs, warrants further studies.

Given the role of LETFs as major transcription factors controlling the expression of many genes in the liver (Cereghini 1996, Hayashi et al. 1999, Schrem et al. 2002), being regulated by GH suggests that they may be part of the transcription factor network mediating $\mathrm{GH}$ regulation of other genes in the liver. A cross examination of the list of genes that have been shown to be regulated by GH (Thompson et al. 2000, Flores-Morales et al. 2001, Olsson et al. 2003, Ahluwalia et al. 2004) and the list of genes that have been identified to contain binding sites for HNF-3 $\gamma$, HNF-3 $\beta$, HNF-6, HNF-4 $\alpha$, C/EBP $\alpha$, or DBP (Schrem et al. 2002, Odom et al. 2004) could identify a number of candidate genes whose expression in the liver may be regulated by GH through these LETFs. For example, the expression of CYP3A4 (Liddle et al. 1998, Jaffe et al. 2002), tyrosine-aminotransferase (TAT) (Ahluwalia et al. 2004), and transferrin (Tf) (Flores-Morales et al. 2001) in the liver were shown to be stimulated by continuous $\mathrm{GH}$ administration. The expression of CYP3A4 (RodriguezAntona et al. 2003), and TAT and Tf (Kaestner et al. 1998) in the liver has also been shown to depend on HNF-3 $\gamma$. Now that HNF-3 $\gamma$ expression is found to be stimulated by $\mathrm{GH}$ in the liver, it is reasonable to suspect that GH may stimulate CYP3A4, TAT, and Tf expression in the liver through increased HNF-3 $\gamma$ expression.
Being regulated by $\mathrm{GH}$ also suggests that the genes containing binding sites for HNF-3 $\gamma$, HNF-3 $\beta$, HNF-6, HNF- $4 \alpha$, C/EBP $\alpha$, and DBP might also be target genes of $\mathrm{GH}$ regulation in the liver. The promoters of many genes have been found to contain binding sites for LETFs (Schrem et al. 2002). A recent study employing promoter microarrays identified that $12 \%, 1 \cdot 7 \%$, and $1.6 \%$ of 13000 gene promoters were bound by HNF- $4 \alpha, \mathrm{HNF}-1 \alpha$, and HNF-6 in hepatocytes respectively (Odom et al. 2004). Thus, the number of genes whose expression in the liver is regulated by GH might be much larger than has been indicated by gene expression studies using cDNA or oligonucleotide microarrays (Thompson et al. 2000, Flores-Morales et al. 2001, Olsson et al. 2003, Ahluwalia et al. 2004).

Compared with HNF-3 $\gamma$, HNF-3 $\beta$, HNF-4 $\alpha$, HNF-6, $\mathrm{C} / \mathrm{EBP} \alpha$, and DBP, the mRNA expression of HNF-1 $\alpha$, HNF-3 $\alpha$, and C/EBP $\beta$ in the bovine liver was not affected by $\mathrm{GH}$. This, however, does not necessarily suggest that HNF-1 $\alpha, \mathrm{HNF}-3 \alpha$, and C/EBP $\beta$ cannot contribute to $\mathrm{GH}$ regulation of gene expression. The ability of a transcription factor to affect gene transcription can be controlled at both concentration and activity, each at multiple levels (Calkhoven \& Ab 1996). It is possible that GH regulates these LETFs (as well as other LETFs) at the translational level, thereby changing their protein concentrations; it is also possible that $\mathrm{GH}$ regulates these LETFs (as well as other LETFs) at the posttranslational level and hence the DNA binding activity or the ability of them to interact with other regulatory proteins. These possibilities remain to be tested in future studies.

In summary, the results of this study indicate that $\mathrm{GH}$ can regulate the mRNA expression of HNF-3 $\gamma$ and five other LETFs including HNF-3 $\beta$, HNF-6, HNF-4 $\alpha$, $\mathrm{C} / \mathrm{EBP} \alpha$, and DBP in the bovine liver. These LETFs, therefore, have great potential to mediate $\mathrm{GH}$ regulation of other genes in the liver. The study also suggests that $\mathrm{GH}$ regulation of HNF-3 $\gamma$ expression in the bovine liver may be mediated by direct binding of STAT 5 to the HNF-3 $\gamma$ promoter.

\section{Acknowledgements}

We are grateful to William Beal and his group for daily animal care and William Swecker Jr for assistance with liver biopsy sampling.

\section{Funding}

The authors declare that there is no conflict of interest that would prejudice the impartiality of this scientific work.

\section{References}

Ahluwalia A, Clodfelter KH \& Waxman DJ 2004 Sexual dimorphism of rat liver gene expression: regulatory role of growth hormone 
revealed by deoxyribonucleic acid microarray analysis. Molecular Endocrinology 18 747-760.

Bergad PL, Shih HM, Towle HC, Schwarzenberg SJ \& Berry SA 1995 Growth hormone induction of hepatic serine protease inhibitor $2 \cdot 1$ transcription is mediated by a Stat5-related factor binding synergistically to two gamma-activated sites. Journal of Biological Chemistry 270 24903-24910.

Calkhoven CF \& Ab G 1996 Multiple steps in the regulation of transcription-factor level and activity. Biochemical Journal 317 329-342.

Cereghini S 1996 Liver-enriched transcription factors and hepatocyte differentiation. FASEB Journal 10 267-282.

Cooper GM \& Sidow A 2003 Genomic regulatory regions: insights from comparative sequence analysis. Current Opinion in Genetics and Development 13 604-610.

Davey HW, McLachlan MJ, Wilkins RJ, Hilton DJ \& Adams TE 1999 STAT5b mediates the GH-induced expression of SOCS-2 and SOCS-3 mRNA in the liver. Molecular and Cellular Endocrinology 158 111-116.

Delesque-Touchard N, Park SH \& Waxman DJ 2000 Synergistic action of hepatocyte nuclear factors 3 and 6 on CYP2C12 gene expression and suppression by growth hormone-activated STAT5b. Proposed model for female specific expression of CYP2C12 in adult rat liver. Journal of Biological Chemistry 275 34173-34182.

Ehret GB, Reichenbach P, Schindler U, Horvath CM, Fritz S, Nabholz M \& Bucher P 2001 DNA binding specificity of different STAT proteins. Comparison of in vitro specificity with natural target sites. Journal of Biological Chemistry 276 6675-6688.

Flores-Morales A, Stahlberg N, Tollet-Egnell P, Lundeberg J, Malek RL, Quackenbush J, Lee NH \& Norstedt G 2001 Microarray analysis of the in vivo effects of hypophysectomy and growth hormone treatment on gene expression in the rat. Endocrinology 142 3163-3176.

Gronowski AM \& Rotwein P 1995 Rapid changes in gene expression after in vivo growth hormone treatment. Endocrinology 136 4741-4748.

Harvey S, Scanes CG \& Daughaday WH 1995 Growth Hormone. Boca Raton: CRC Press.

Hayashi Y, Wang W, Ninomiya T, Nagano H, Ohta K \& Itoh H 1999 Liver enriched transcription factors and differentiation of hepatocellular carcinoma. Molecular Pathology 52 19-24.

Herrington J \& Carter-Su C 2001 Signaling pathways activated by the growth hormone receptor. Trends in Endocrinology and Metabolism 12 252-257.

Jaffe CA, Turgeon DK, Lown K, Demott-Friberg R \& Watkins PB 2002 Growth hormone secretion pattern is an independent regulator of growth hormone actions in humans. American Journal of Physiology - Endocrinology and Metabolism 283 E1008-E1015.

Jiang H \& Lucy MC 2001 Involvement of hepatocyte nuclear factor-4 in the expression of the growth hormone receptor $1 \mathrm{~A}$ messenger ribonucleic acid in bovine liver. Molecular Endocrinology 15 1023-1034.

Kaestner KH, Hiemisch H \& Schutz G 1998 Targeted disruption of the gene encoding hepatocyte nuclear factor 3 gamma results in reduced transcription of hepatocyte-specific genes. Molecular and Cellular Biology 18 4245-4251.

Lahuna O, Fernandez L, Karlsson H, Maiter D, Lemaigre FP, Rousseau GG, Gustafsson J \& Mode A 1997 Expression of hepatocyte nuclear factor 6 in rat liver is sex-dependent and regulated by growth hormone. PNAS 94 12309-12313.

Lahuna O, Rastegar M, Maiter D, Thissen JP, Lemaigre FP \& Rousseau GG 2000 Involvement of STAT5 (signal transducer and activator of transcription 5) and HNF-4 (hepatocyte nuclear factor 4) in the transcriptional control of the hnf6 gene by growth hormone. Molecular Endocrinology 14 285-294.

Le Stunff C, Gronowski AM \& Rotwein P 1996 Contrasting acute in vivo nuclear actions of growth hormone and prolactin. Molecular and Cellular Endocrinology 121 109-117.
Lemaigre FP, Durviaux SM, Truong O, Lannoy VJ, Hsuan JJ \& Rousseau GG 1996 Hepatocyte nuclear factor 6, a transcription factor that contains a novel type of homeodomain and a single cut domain. PNAS 93 9460-9464.

Lemmey AB, Glassford J, Flick-Smith HC, Holly JM \& Pell JM 1997 Differential regulation of tissue insulin-like growth factor-binding protein (IGFBP)-3, IGF-I and IGF type 1 receptor mRNA levels, and serum IGF-I and IGFBP concentrations by growth hormone and IGF-I. Journal of Endocrinology 154 319-328.

Liao J, Piwien-Pilipuk G, Ross SE, Hodge CL, Sealy L, MacDougald OA \& Schwartz J 1999 CCAAT/enhancer-binding protein beta (C/EBPbeta) and C/EBPdelta contribute to growth hormone-regulated transcription of c-fos. Journal of Biological Chemistry 274 31597-31604.

Liddle C, Goodwin BJ, George J, Tapner M \& Farrell GC 1998 Separate and interactive regulation of cytochrome P450 3A4 by triiodothyronine, dexamethasone, and growth hormone in cultured hepatocytes. Journal of Clinical Endocrinology and Metabolism $\mathbf{8 3}$ 2411-2416.

Mathews LS, Norstedt G \& Palmiter RD 1986 Regulation of insulin-like growth factor I gene expression by growth hormone. PNAS 83 9343-9347.

Odom DT, Zizlsperger N, Gordon DB, Bell GW, Rinaldi NJ, Murray HL, Volkert TL, Schreiber J, Rolfe PA, Gifford DK, Fraenkel E, Bell GI \& Young RA 2004 Control of pancreas and liver gene expression by HNF transcription factors. Science $\mathbf{3 0 3}$ 1378-1381.

Olsson B, Bohlooly YM, Brusehed O, Isaksson OG, Ahren B, Olofsson SO, Oscarsson J \& Tornell J 2003 Bovine growth hormone-transgenic mice have major alterations in hepatic expression of metabolic genes. American Journal of Physiology Endocrinology and Metabolism 285 E504-E511.

Ooi GT, Cohen FJ, Tseng LY, Rechler MM \& Boisclair YR 1997 Growth hormone stimulates transcription of the gene encoding the acid-labile subunit (ALS) of the circulating insulin-like growth factor-binding protein complex and ALS promoter activity in rat liver. Molecular Endocrinology 11 997-1007.

Oxender WD, Askew EW, Benson JD \& Emery RS 1971 Biopsy of liver, adipose tissue and mammary gland of lactating cows. Journal of Dairy Science 54 286-288.

Park SH \& Waxman DJ 2001 Inhibitory cross-talk between STAT5b and liver nuclear factor HNF3 beta: impact on the regulation of growth hormone pulse-stimulated, male-specific liver cytochrome P-450 gene expression. Journal of Biological Chemistry 276 43031-43039.

Rastegar M, Lemaigre FP \& Rousseau GG 2000 Control of gene expression by growth hormone in liver: key role of a network of transcription factors. Molecular and Cellular Endocrinology $1641-4$.

Rodriguez-Antona C, Bort R, Jover R, Tindberg N, Ingelman-Sundberg M, Gomez-Lechon MJ \& Castell JV 2003 Transcriptional regulation of human CYP3A4 basal expression by CCAAT enhancer-binding protein alpha and hepatocyte nuclear factor-3 gamma. Molecular Pharmacology 63 1180-1189.

Sasaki Y, Takahashi Y, Nakayama K \& Kamataki T 1999 Cooperative regulation of CYP2C12 gene expression by STAT5 and liver-specific factors in female rats. Journal of Biological Chemistry 274 37117-37124.

Schrem H, Klempnauer J \& Borlak J 2002 Liver-enriched transcription factors in liver function and development. Part I: the hepatocyte nuclear factor network and liver-specific gene expression. Pharmacological Reviews 54 129-158.

Schwartz J, Huo JS \& Piwien-Pilipuk G 2002 Growth hormone regulated gene expression. Minerva Endocrinologica 27 231-241.

Seneviratne C, Luo JM \& Murphy LJ 1990 Transcriptional regulation of rat insulin-like growth factor-binding protein-1 expression by growth hormone. Molecular Endocrinology 4 1199-1204. 
Strand P, Carlsson L, Rask K, Skrtic S, Ekberg S, Hedin L, Oscarsson J \& Jansson JO 2000 Growth hormone induces CCAAT/enhancer binding protein alpha (C/EBPalpha) in cultured rat hepatocytes. Journal of Hepatology 32 618-626.

Thomas JW, Touchman JW, Blakesley RW, Bouffard GG, Beckstrom-Sternberg SM, Margulies EH, Blanchette M, Siepel AC, Thomas PJ, McDowell JC et al. 2003 Comparative analyses of multi-species sequences from targeted genomic regions. Nature $\mathbf{4 2 4}$ 788-793.

Thompson BJ, Shang CA \& Waters MJ 2000 Identification of genes induced by growth hormone in rat liver using cDNA arrays. Endocrinology 141 4321-4324.

Tollet-Egnell P, Flores-Morales A, Stavreus-Evers A, Sahlin L \& Norstedt G 1999 Growth hormone regulation of SOCS-2, SOCS-3, and CIS messenger ribonucleic acid expression in the rat. Endocrinology 140 3693-3704.

Valera A, Rodriguez-Gil JE, Yun JS, McGrane MM, Hanson RW \& Bosch F 1993 Glucose metabolism in transgenic mice containing a chimeric P-enolpyruvate carboxykinase/bovine growth hormone gene. FASEB Journal 7 791-800.
Wang Y, Eleswarapu S, Beal WE, Swecker WS Jr, Akers RM \& Jiang H 2003 Reduced serum insulin-like growth factor (IGF)-I is associated with reduced liver IGF-I mRNA and liver growth hormone receptor mRNA in food-deprived cattle. Journal of Nutrition 133 2555-2560.

Woelfle J \& Rotwein P 2004 In vivo regulation of growth hormone-stimulated gene transcription by STAT5b. American Journal of Physiology - Endocrinology and Metabolism 286 E393-E401.

Woelfle J, Billiard J \& Rotwein P 2003 Acute control of insulin-like growth factor-I gene transcription by growth hormone through Stat5b. Journal of Biological Chemistry 278 22696-22702.

Yoon JB, Berry SA, Seelig S \& Towle HC 1990 An inducible nuclear factor binds to a growth hormone-regulated gene. Journal of Biological Chemistry 265 19947-19954.

Received 23 September 2004

Accepted 15 October 2004 